\title{
Performa produksi Broiler starter akibat cekaman panas dan perbedaan awal waktu pemberian pakan
}

\section{Performance production of Broiler starter due to heat stress and different initial feeding}

\author{
Liborio Ximenes, Pratiwi Trisunuwati, dan Muharlien* \\ Program Studi Magister Ilmu Ternak, Fakultas Peternakan Universitas Brawijaya \\ Jl. Veteran, Malang (65145)
}

Submitted: 12 December 2017, Accepted: 04 August 2018

\begin{abstract}
ABSTRAK : Penelitian ini bertujuan untuk mengetahui performa produksi (konsumsi pakan, pertambahan bobot badan dan konversi pakan) broiler starter akibat cekaman panas dan perbedaan awal waktu pemberian pakan. Materi penelitian ini adalah 64 ekor DOC broiler jantan strain Lohmann dengan rataan bobot badan 47,98 $\pm 2,24$ g. Metode penelitian yang digunakan adalah percobaan, dengan Rancangan Acak Kelompok faktorial 2x2 dengan 4 ulangan. Kombinasi perlakuan sebagai berikut: $\mathrm{S} 1 \mathrm{~W} 1=$ suhu rendah, pakan 12 jam pasca menetas; S1W2= suhu rendah, pakan 24 jam pasca menetas; S2W1= suhu tinggi, pakan 12 jam pasca menetas; S2W2= suhu tinggi, pakan 24 jam pasca menetas. Data dianalisis menggunakan uji sidik ragam (ANOVA). Apabila berbeda nyata $(\mathrm{P}<0,05)$ atau sangat nyata $(\mathrm{P}<0,01)$ dilanjutkan dengan uji Duncan's. Hasil penelitian menunjukkan bahwa konsumsi pakan terdapat perbedaan sangat nyata $(\mathrm{P}<0,01)$ akibat perlakuan suhu cekaman panas dan awal waktu pemberian pakan. Perlakuan awal waktu pemberian pakan memberikan pengaruh nyata $(\mathrm{P}<0,05)$ terhadap pertambahan bobot badan dan konversi pakan. Kesimpulan dari penelitian ini adalah cekaman panas berdampak negatif terhadap performa broiler starter. Perbedaan awal waktu pemberian pakan pasca menetas mempengaruhi konsumsi pakan, pertambahan bobot badan dan konversi pakan broiler starter.
\end{abstract}

Kata kunci : cekaman panas, awal waktu pemberian pakan, performa

\begin{abstract}
The study was conducted to know performance (feed consumption, body weight gain and feed conversion) response of broiler starter due to heat stress and different initial feeding. The material used in this study was 64 male DOC broilers of Lohmann strain with average of initial weight $47,98 \pm 2,24$ g. The experiment was designed based on Randomized Blok Design with $2 \times 2$ factorial and four replications. The treatment combinations as follow: S1W1= low temperature, feeding 12 hours post-hatching; S1W2 = low temperature, feeding 24 hours post-hatching; S2W1= high temperature, feeding 12 hours post-hatching; S2W2 = high temperature, feeding 24 hours posthatching. The data were analyzed by using ANOVA. If there was significant effect $(\mathrm{P}<0.05)$ or very significant effect $(\mathrm{P}<0.01)$ followed by Duncan's test. The result showed that feed consumption had very significant effect $(\mathrm{P}<0.01)$ due to heat stress treatment and initial feeding. The initial feeding treatment had significant effect $(\mathrm{P}<0.05)$ to the body weight gain and feed conversion. It concluded that heat stress affected negatively to the performance of broiler starter. The initial feeding has significantly affected to the feed consumption, body weight gain and feed conversion in broiler starter.
\end{abstract}

Keywords : heat stress, initial feeding, performance.

\footnotetext{
*Corresponding Author: muharlien@gmail.com
} 


\section{PENDAHULUAN}

Manajemen awal waktu pemberian pakan memegang peranan penting dalam upaya mengoptimalkan performa produksi broiler khususnya pada fase starter. Keterlambatan awal waktu pemberian pakan yang masih dapat ditolerir adalah sekitar 24 jam pasca menetas, sedangkan bila lebih dari 24 jam, maka bobot standar saat panen tidak akan tercapai. Bhanja $e t$ al., (2009) melaporkan bahwa ayam yang diberi pakan dalam waktu 24 jam setelah menetas mempunyai bobot badan yang lebih tinggi pada umur 5 minggu dibandingkan dengan yang tertunda mendapatkan pakan lebih lama.

Beberapa hari pasca menetas merupakan periode atau waktu kritis dalam pertumbuhan dan perkembangan tubuh broiler komersial. Kesalahan manajemen pada periode ini dapat menyebabkan terganggunya pertumbuhan pada periode selanjutnya. Sehubungan dengan hal tersebut, maka asupan pakan tidak boleh mengalami keterlambatan agar kebutuhan energi dan protein segera terpenuhi (Wahju, 2004). Menurut Bhanja et al., (2009), dengan adanya pakan atau nutrisi yang memenuhi kebutuhan broiler menyebabkan saluran pencernaan akan berkembang dan enzim-enzim percernaan dapat secepatnya disekresikan.

Permasalahan lain yang dihadapi usaha peternakan broiler di wilayah beriklim tropis yaitu suhu lingkungan yang tinggi diatas suhu nyaman ayam. Suhu nyaman broiler adalah $18-22^{\circ} \mathrm{C}$ (Charles, 2004). Di wilayah tropis (misalnya Indonesia), suhu lingkungan siang hari dapat mencapai $34^{\circ} \mathrm{C}$ (Kusnadi dan Rahim, 2009). Hal ini memicu terjadinya cekaman panas. Kondisi ini diperparah dengan manajemen awal waktu pemberian pakan pasca menetas yang salah sehingga pertumbuhan broiler starter menjadi tidak maksimal (Tamzil et al., 2013).

Penelitian Kusnadi

menunjukkan bahwa_broiler yang dipelihara pada umur ( 2 sampai 3 minggu) dengan suhu $32^{\circ} \mathrm{C}$, menghasilkan konsumsi pakan 1484 g/ekor dan menghasilkan pertambahan bobot badan 692 g/ekor. Sedang yang dipelihara pada suhu 22 mempunyai angka konsumsi pakan2462 g/ekor dan pertambahan bobot badan 1322 g/ekor. Hal tersebut menunjukan bahwa konsumsi pakan dan pertambahan bobot hidup broiler yang dipelihara pada suhu dingin lebih tinggi dibanding yang dipelihara di suhu panas. berumur 2-5 minggu pada suhu pemeliharaan $32^{\circ} \mathrm{C}$ masing-masing $1484 \mathrm{~g}$ dan $692 \mathrm{~g}$, nyata lebih rendah dibandingkan pada suhu $22^{\circ} \mathrm{C}$ masingmasing $2462 \mathrm{~g}$ dan $1322 \mathrm{~g}$. Hal sebaliknya terjadi pada konversi pakan_yakni 2,14 pada suhu panas dan 1,86 pada suhu dingin. Berdasarkan uraian diatas, perlu dilakukan penelitian untuk mengetahuiperforma produksi broiler starter akibat cekaman panas dan perbedaan awal waktu pemberian pakan pasca menetas.

\section{MATERI DAN METODE}

Penelitian ini dilaksanakan mulai 12 Mei - 20 September 2017. Materi penelitian yang digunakan adalah 64 ekor DOC broiler, dengan kriteria jenis kelamin jantan dan rataan bobot badan standar sebesar 47,98 $\pm 2,24$ g. Metode penelitian adalah penelitian experimental in vivo menggunakan Rancangan acak kelompok (RAK) faktorial (2x2) dengan 4 ulangan. Pengelompokan berdasarkan suhu setiap minggu yang tidak sama. Faktor pertama adalah perlakuan cekaman suhu (S) dan faktor kedua adalah awal waktu pemberian pakan (W). Kombinasi perlakuan sebagai berikut: S1W1 = suhu rendah, diberi pakan 12 jam pasca menetas; $\mathrm{S} 1 \mathrm{~W} 2=$ suhu rendah, diberi pakan 24 jam pasca menetas; S2W1 = suhu tinggi, diberi pakan 12 jam pasca menetas; S2W2= suhu tinggi, diberi pakan 24 jam pasca menetas. Pengaturan suhu perlakuan sebagai 
berikut: Suhu rendah $=$ minggu I (31$\left.33^{\circ} \mathrm{C}\right)$, minggu II $\left(28-30^{\circ} \mathrm{C}\right)$, minggu III $\left(26-28^{\circ} \mathrm{C}\right)$. Suhu tinggi $=$ minggu $\mathrm{I}$ $\left(34-36^{\circ} \mathrm{C}\right)$, minggu II $\left(31-33^{\circ} \mathrm{C}\right)$, minggu III $\left(29-31^{0} \mathrm{C}\right)$.

Ternak dipelihara selama 21 hari yang terbagi dalam 16 unit kandang percobaan masing-masing berukuran 1x1x1 m dan dilengkapi dengan tempat pakan, minum thermometer, thermostat dan lampu pemanas 60 watt. Perlakuan cekaman panas menggunakan bantuan sumber panas beruapa lampu berdaya 60 watt. Masing-masing blok suhu dilengkapi dengan termostat dan termometer untuk mengatur suhu agar tetap stabil pada kondisi sesuai perlakuan cekaman panas. Kandang ditutup dengan plastik berwarna putih sebagai upaya menjaga suhu tetap stabil. Pada siang hari, sisi samping tirai dibuka agar amonia dalam kandang keluar dan tidak menumpuk di dalam. Pada sore hari sampai dengan siang hari tirai ditutup.

Pengukuran suhu dan kelembaban dilakukan pada pagi hari (pukul 06.30 WIB), siang hari (pukul 12.30 WIB) dan sore hari (pukul 17.30 WIB). Pengukuran suhu dan kelembaban dilakukan dengan bantuan termohigrometer yang terpasang pada sisi kandang. Data suhu dan kelembaban yang diperoleh pada pagi, siang dan sore hari kemudian dirata-rata untuk mendapatkan rataan suhu dan kelembaban mingguan.

Data konsumsi pakan, pertambahan bobot badan dan konversi pakan di ukur secara mingguan. Pertambahan bobot badan (g/ekor), diperoleh dari hasil pengurangan bobot badan akhir dikurangi dengan bobot badan awal. Konsumsi pakan (g/ekor), diperoleh dari total pemberian pakan yang diberikan dikurangi dengan sisa pakan. Konversi pakan, diperoleh dari hasil pembagian total konsumsi pakan dengan pertambahan bobot badan selama periode pengukuran. Data yang diperoleh dianalisis menggunakan uji sidik ragam
(ANOVA) dengan bantuan Program Microsoft Excel 2016. Apabila berbeda nyata $(\mathrm{P}<0,05)$ atau sangat nyata $(\mathrm{P}<0,01)$ dilanjutkan dengan uji Duncan's.

\section{HASIL DAN PEMBAHASAN}

\section{Pengaruh perlakuan terhadap konsumsi pakan}

Total konsumsi pakan selama 3 minggu pemeliharaan broiler (Tabel 1) menunjukkan perbedaan sangat nyata $(\mathrm{P}<0,01)$. Perbedaan sangat nyata ini terjadi diakibatkan oleh masing-masing faktor perlakuan baik pada faktor perlakuan suhu maupun faktor awal waktu pemberian pakan yang berbeda. Pada faktor perlakuan awal waktu pemberian pakan, perbedaan sudah tampak sejak minggu pertama pemeliharaan. Sedangkan pada faktor perlakuan suhu, perbedaan tampak mulai minggu kedua pemeliharaan. Pada tabel 6 juga dapat dilihat bahwa rataan total konsumsi pakan broiler selama 3 minggu pemeliharaan mulai dari yang terbesar secara berturut-turut yaitu S1W1 $(1181,04 \pm 8,71 \mathrm{~g})$, S2W1 $(1172,75 \pm 2,25$ g), S1W2 $(1165,79 \pm 0,66 \mathrm{~g})$ dan S2W2 $(1144,03 \pm 12,37 \mathrm{~g})$.

Perbedaan yang sangat nyata pada faktor perlakuan perbedaan awal waktu pemberian pakan pasca menetas terhadap konsumsi pakan sejak minggu pertama pemeliharaan membuktikan bahwa manajemen pemberian pakan berdampak pada konsumsi broiler periode starter dimana perlakuan pemberian pakan 12 jam pasca menetas menghasilkan konsumsi pakan lebih tinggi daripada perlakuan pemberian pakan 24 jam pasca menetas. Dibuktikan dengan rataan total konsumsi pakan selama 3 minggu pemeliharaan pada perlakuan W1 dan W2 yang berbeda sangat nyata, dimana rataan total konsumsi pakan perlakuan W1 yaitu sebesar 1176,90 $\pm 7,37 \mathrm{~g}$, jauh lebih tinggi daripada W2 yang hanya $1154,91 \pm 14,18 \mathrm{~g}$. 
Tabel 1. Total rataan konsumsi pakan selama 3 minggu pemeliharaan (gram/ekor)

\begin{tabular}{|c|c|c|c|c|}
\hline \multirow{2}{*}{ Minggu ke- } & \multirow{2}{*}{ Suhu $(\mathrm{S})$} & \multicolumn{2}{|c|}{ Awal waktu pemberian pakan (W) } & \multirow{2}{*}{ Rataan } \\
\hline & & W1 & W2 & \\
\hline \multirow{3}{*}{ I } & S1 & $128,11 \pm 3,73$ & $125,63 \pm 0,77$ & $126,87 \pm 2,82$ \\
\hline & $\mathrm{S} 2$ & $128,88 \pm 1,11$ & $121,57 \pm 4,02$ & $125,22 \pm 4,76$ \\
\hline & Rataan & $128,49 \pm 2,58^{\mathrm{b}}$ & $123,60 \pm 3,45^{\mathrm{a}}$ & \\
\hline \multirow{3}{*}{ II } & S1 & $383,73 \pm 3,55$ & $378,83 \pm 0,43$ & $381,28 \pm 3,51^{\mathrm{b}}$ \\
\hline & $\mathrm{S} 2$ & $378,58 \pm 0,40$ & $366,08 \pm 6,30$ & $372,33 \pm 7,86^{\mathrm{a}}$ \\
\hline & Rataan & $381,15 \pm 3,61^{b}$ & $372,45 \pm 7,97^{\mathrm{a}}$ & \\
\hline \multirow{3}{*}{ III } & S1 & $669,21 \pm 1,50$ & $661,33 \pm 0,45$ & $665,27 \pm 4,33^{\mathrm{b}}$ \\
\hline & $\mathrm{S} 2$ & $665,29 \pm 1,04$ & $656,39 \pm 2,07$ & $660,84 \pm 4,99^{a}$ \\
\hline & Rataan & $667,25 \pm 2,41^{b}$ & $658,86 \pm 2,98^{\mathrm{a}}$ & \\
\hline \multirow{3}{*}{ Total } & S1 & $1181,04 \pm 8,71$ & $1165,79 \pm 0,66$ & $1173,42 \pm 9,96^{\mathrm{b}}$ \\
\hline & $\mathrm{S} 2$ & $1172,75 \pm 2,25$ & $1144,03 \pm 12,37$ & $1158,39 \pm 17,42^{\mathrm{a}}$ \\
\hline & Rataan & $1176,90 \pm 7,37^{b}$ & $1154,91 \pm 14,18^{a}$ & \\
\hline
\end{tabular}

Keterangan: Superskrip huruf yang berbeda pada baris atau kolom yang sama (a, b) menunjukkan berbeda sangat nyata $(\mathrm{P}<0,01) . \mathrm{S} 1=$ Suhu rendah; $\mathrm{S} 2=$ Suhu tinggi; $\mathrm{W} 1=$ Awal waktu pemberian pakan $12 \mathrm{jam}$; $\mathrm{W} 2=$ Awal waktu pemberian pakan $24 \mathrm{jam}$.

Faktor perlakuan suhu yang menunjukkan perbedaan yang sangat nyata mulai minggu kedua pemeliharaan juga membuktikan bahwa cekaman panas dapat menurunkan konsumsi pakan pada broiler periode starter. Penurunan ini disebabkan karena pada kondisi cekaman panas, ternak cenderung memperbanyak mengkonsumsi air minum daripada mengkonsumsi pakan. Hal ini dilakukan untuk menstabilkan suhu tubuh dan mempertahankan cairan dalam tubuh yang terbuang akibat pelepasan panas yang berlebihan yang disebabkan oleh suhu lingkungan yang panas diatas suhu nyaman ayam (Nort and Bell, 1990; Bell and Weaver, 2002). Penurunan total konsumsi pakan ini dibuktikan dengan rataan total konsumsi pakan selama 3 minggu pemeliharaan pada perlakuan S2 $(1158,39 \pm 17,42 \mathrm{~g})$ lebih rendah daripada S1 $(1173,42 \pm 9,96$ g). Penelitian Yunianto (1999), melaporkan bahwa total konsumsi pakan menunjukkan peningkatan sebesar $10,03 \%$ pada kondisi cekaman dingin dan menurun sebesar 9,98\% dalam kondisi cekaman panas pada broiler yang dipelihara pada suhu dingin $\left(16^{\circ} \mathrm{C}\right)$, suhu panas $\left(34^{\circ} \mathrm{C}\right)$ dan sebagai kontrol sebesar $25^{\circ} \mathrm{C}$. Hal ini membuktikan total konsumsi pakan pada broiler sangat dipengaruhi oleh suhu lingkungan pemeliharaan.

Suhu di tempat penetasan adalah sekitar $35^{\circ} \mathrm{C}$, sehingga peternak tidak perlu khawatir ayam terkena stress panas pada awal kehidupan (minggu pertama). Stress panas baru akan berpengaruh pada ayam yang lebih dewasa, karena broiler termasuk ayam yang mempunyai pertumbuhan berat dengan cepat, padahal luas permukaan tubuh ayam yang diperlukan untuk membuang panas secara konduksi dan konveksi hanya meningkat $3 / 4$ dibandingkan dengan laju pertambahan berat badannya. Menjadi wajar dan biasa dipahami mengapa hasil penelitian ini pada perlakuan suhu memberikan hasil tidak berbeda nyata pada minggu pertama, tetapi justru berpengaruh secara nyata pada minggu kedua untuk parameter konsumsi pakan. Total konsumsi pakan broiler periode starter selama 3 minggu pemeliharaan ditampilkan pada Gambar 1. 


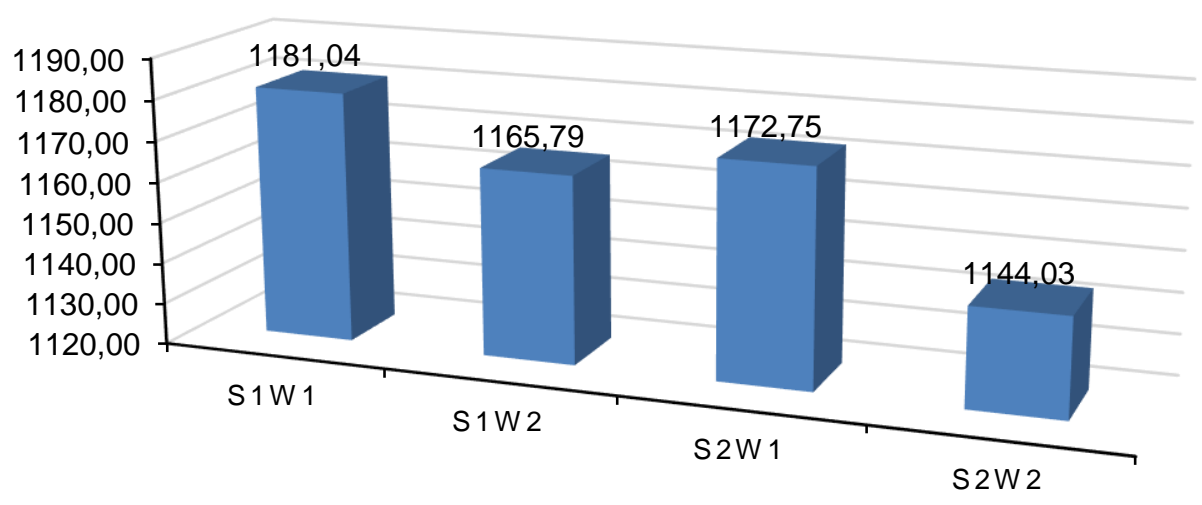

Gambar 1. Total konsumsi pakan

Kombinasi perlakuan suhu rendah dan awal waktu pemberian pakan 12 jam pasca menetas terhadap total konsumsi pakan merupakan kombinasi terbaik dalam pemeliharaan broiler periode starter walaupun interaksi dari kedua faktor tersebut (faktor suhu dan faktor awal waktu pemberian pakan pasca menetas) tidak menunjukkan perbedaan signifikan secara uji statistik, tetapi terbukti mampu meningkatkan total konsumsi pakan selama 3 minggu pemeliharaan pada broiler periode starter. Peningkatan total konsumsi pakan ini diharapkan juga berdampak posistif terhadap PBB dan FCR broiler periode starter, sehingga performa broiler periode starter dapat tercapai secara maksimal.

\section{Pengaruh perlakuan terhadap pertambahan bobot badan (PBB)}

Total PBB broiler selama 3 minggu pemeliharaan (Tabel 2) menunjukkan perbedaan sangat nyata $(\mathrm{P}<0,01)$ yang disebabkan oleh faktor perlakuan perbedaan awal waktu pemberian pakan pasca menetas sedangkan faktor perlakuan suhu tidak menunjukkan hasil yang berbeda nyata. Pada faktor perlakuan awal waktu pemberian pakan, perbedaan sudah tampak mulai dari minggu kedua pemeliharaan. Pada tabel 7 juga dapat dilihat bahwa rataan total PBB broiler selama 3 minggu pemeliharaan mulai dari yang terbesar secara berturut-turut yaitu S1W1 (978,19 \pm 51,32 g), S2W1 (974,67 \pm 46,82 g), S1W2 (887,92 \pm 47,91 g) dan S2W2 (795,04 $\pm 119,38 \mathrm{~g})$. Hasil ini berbanding lurus dengan rataan total konsumsi pakan selama 3 minggu pemeliharaan broiler periode starter.

Perlakuan perbedaan awal waktu pemberian pakan pasca menetas memberikan hasil berpengaruh sangat nyata terhadap total PBB, bahkan sudah mulai tampak pada minggu kedua pemeliharaan seperti terlihat pada tabel 7 di atas. Hal ini memberi arti bahwa pemberian pakan pada ayam seawal mungkin diduga memang berpengaruh terhadap perkembangan usus. Vili akan berkembang sempurna, peristaltik akan dipacu seawal mungkin, sehingga sistem transport dalam usus berkembang baik. Enzim pankreas dan garam empedu digertak seawal mungkin, seiring dengan makanan yang masuk. Hal ini kemudian akan menyebabkan penyerapan zat nutrisi menjadilebih maksimal sehingga ayam yang diberi pakan lebih dini pasca menetas mempunyai rataan total PBB yang optimal. 
Tabel 2. Total rataan PBB selama 3 minggu pemeliharaan (gram/ekor)

\begin{tabular}{lllcc}
\hline \multirow{2}{*}{$\begin{array}{c}\text { Minggu } \\
\text { ke- }\end{array}$} & Suhu $(\mathrm{S})$ & \multicolumn{2}{c}{ Awal waktu pemberian pakan $(\mathrm{W})$} & \multirow{2}{*}{ Rataan } \\
\cline { 3 - 4 } I & S1 & $113,38 \pm 6,50$ & $105,88 \pm 7,36$ & $109,63 \pm 7,66$ \\
& S2 & $108,56 \pm 7,36$ & $102,90 \pm 5,69$ & $105,73 \pm 6,80$ \\
& Rataan & $110,97 \pm 6,92$ & $104,39 \pm 6,39$ & \\
II & S1 & $269,44 \pm 22,70$ & $253,94 \pm 13,48$ & $261,69 \pm 19,17$ \\
& S2 & $265,50 \pm 19,76$ & $234,04 \pm 15,00$ & $249,77 \pm 23,38$ \\
& Rataan & $267,47 \pm 19,82^{\mathrm{B}}$ & $243,99 \pm 16,95^{\mathrm{A}}$ & \\
\multirow{3}{*}{ III } & S1 & $595,38 \pm 70,78$ & $528,10 \pm 59,73$ & $561,74 \pm 70,49$ \\
& S2 & $600,60 \pm 31,83$ & $458,10 \pm 111,11$ & $529,35 \pm 107,36$ \\
& Rataan & $597,99 \pm 50,88^{\mathrm{B}}$ & $493,10 \pm 90,66^{\mathrm{A}}$ & \\
\hline \multirow{3}{*}{ Total } & S1 & $978,19 \pm 51,32$ & $887,92 \pm 47,91$ & $933,05 \pm 66,64$ \\
& S2 & $974,67 \pm 46,82$ & $795,04 \pm 119,38$ & $884,85 \pm 127,54$ \\
& Rataan & $976,43 \pm 45,52^{\mathrm{b}}$ & $841,48 \pm 97,75^{\mathrm{a}}$ &
\end{tabular}

Keterangan: Superskrip huruf yang berbeda pada baris yang sama $(a, b)$ menunjukkan berbeda sangat nyata $(\mathrm{P}<0,01)$. Superskrip huruf yang berbeda pada baris yang sama $(\mathrm{A}, \mathrm{B})$ menunjukkan berbeda nyata $(\mathrm{P}<0,05)$. $\mathrm{S} 1=$ Suhu rendah; $\mathrm{S} 2=$ Suhu tinggi; $\mathrm{W} 1=$ Awal waktu pemberian pakan $12 \mathrm{jam}$; W2= Awal waktu pemberian pakan 24 jam.

Perbedaan yang sangat nyata pada faktor perlakuan perbedaan awal waktu pemberian pakan pasca menetas terhadap PBB mulai minggu kedua pemeliharaan sejalan dengan konsumsi pakan broiler periode starter. Peningkatan konsumsi pakan ini menyebabkan total PBB juga mengalami kenaikan. Hal ini dibuktikan dengan rataan total PBB selama 3 minggu pemeliharaan pada perlakuan W1 sebesar 976,43 \pm 45,52 g, jauh lebih tinggi daripada W2 yang hanya $841,48 \pm 97,75 \mathrm{~g}$. Hasil penelitian ini didukung dengan hasil penelitian Luet al., (2007) yang menyatakan bahwa PBB broiler umur 5-8 minggu yang dipelihara pada suhu $34^{\circ} \mathrm{C}$ dengan pemberian pakanad libitumadalah 22,29 g/hari, nyata lebih rendah dibandingkan dengan yang dipelihara pada suhu $21^{\circ} \mathrm{C}$ dengan pemberian pakanad libitum yakni $61,45 \mathrm{~g} /$ hari. $\mathrm{PBB}$ ayam yang dipelihara pada suhu $21^{\circ} \mathrm{C}$ dengan pemberian pakan yang dibatasi sesuai padasuhu $34^{\circ} \mathrm{C}$ adalah 29,45 g/hari, nyata lebih tinggi pula dibandingkan suhu $34^{\circ} \mathrm{C}$ dengan pemberian pakanad libitumyang sebesar 22,29 g/hari.Geraert et al., (1996) juga melaporkan bahwa akan terjadi penurunan bobot badan sebanyak 14\% pada umur 2 sampai 4 minggu dan penurunan sebesar $24 \%$ pada umur 4 sampai 6 minggu pada unggas yang dipelihara di lingkungan dengan temperatur sampai $32^{\circ} \mathrm{C}$.

Pengaruh faktor perlakuan suhu terhadap total PBB broiler selama 3 minggu pemeliharaan pada penelitian ini tidak menunjukkan perbedaan signifikan. Walaupun demikian, rataan total PBB pada perlakuan S2 lebih rendah daripada S1. Rendahnya PBB pada perlakuan S2 dikarenakan ternak mengalami cekaman panas yang berdampak pada penurunan konsumsi pakan yang berdampak besar pada PBB yang juga mengalami penurunan. Penurunan total PBB ini dibuktikan dengan rataan total PBB selama 3 minggu pemeliharaan pada perlakuan S2 yang hanya sebesar 884,85 $\pm 127,54 \mathrm{~g}$, lebih rendah daripada $\mathrm{S} 1$ yang mencapai $933,05 \pm 66,64 \mathrm{~g}$. Hal ini sesuai dengan penelitian Yunianto (1999) yang melaporkan bahwa ayam pedaging yang dipelihara pada suhu $25^{\circ} \mathrm{C}$ berbeda sangat 
nyata dibandingkan yang dipelihara pada suhu $35^{\circ} \mathrm{C}$, pada respon PBB. Pada ayam yang dipelihara pada suhu $16^{\circ} \mathrm{C}$ ternyata memberi hasil PBB yang lebih jelek daripada kontrol $25^{\circ} \mathrm{C}$. Total PBB broiler periode starter selama 3 minggu pemeliharaan ditampilkan pada Gambar 2.

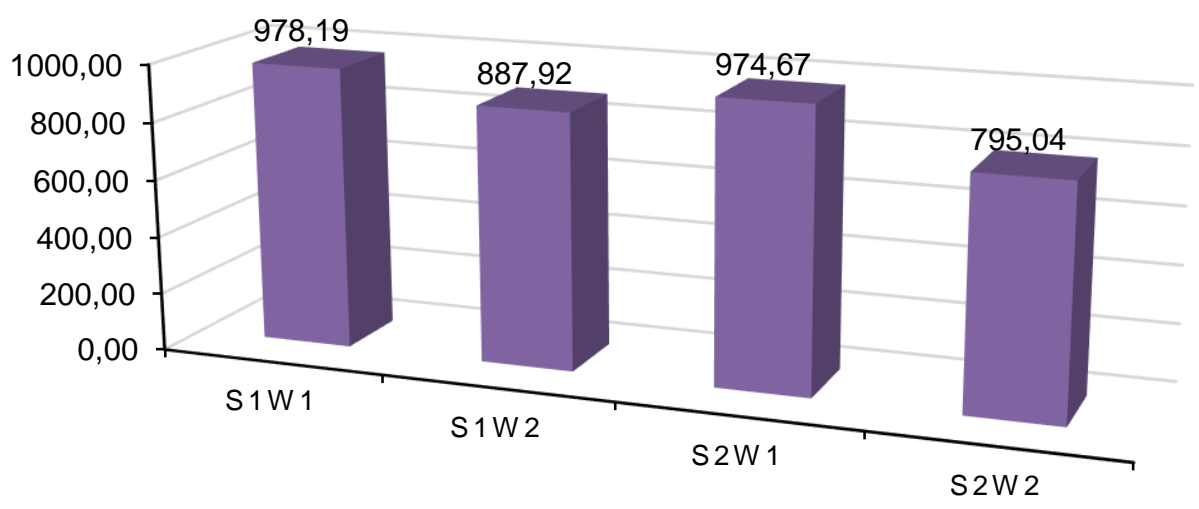

Gambar 2. Total PBB

Kombinasi perlakuan suhu rendah dan awal waktu pemberian pakan 12 jam pasca menetas merupakan kombinasi terbaik terhadap rataan total PBB selama 3 minggu pemeliharaan pada broiler periode starter walaupun interaksi dari kedua faktor tersebut (faktor suhu dan faktor awal waktu pemberian pakan pasca menetas) tidak menunjukkan perbedaan signifikan secara uji statistik, tetapi terbukti mampu meningkatkan total PBB broiler periode starter.

\section{Pengaruh perlakuan terhadap konversi pakan (FCR)}

Nilai FCR broiler selama 3 minggu pemeliharaan (Tabel 3) menunjukkan perbedaan yang nyata $(\mathrm{P}<0,05)$ yang disebabkan oleh faktor perlakuan perbedaan awal waktu pemberian pakan pasca menetas sedangkan faktor perlakuan suhu tidak memberikan perbedaan yang nyata. Pada faktor perlakuan awal waktu pemberian pakan, perbedaan baru tampak pada minggu ketiga pemeliharaan sehingga menyebabkan total FCR selama 3 minggu pemeliharaan berbeda nyata. Pada tabel 8 juga dapat dilihat bahwa rataan total FCR broiler selama 3 minggu pemeliharaan mulai dari yang terkecil secara berturutturut yaitu S1W1 (1,21 $\pm 0,06), \mathrm{S} 2 \mathrm{~W} 1$ $(1,21 \pm 0,06), \operatorname{S1W} 2(1,32 \pm 0,07)$ dan S2W2 (1,46 $\pm 0,23)$. Hasil ini selaras dengan rataan total konsumsi pakan dan PBB selama 3 minggu pemeliharaan broiler periode starter pada penelitian ini.

Perbedaan yang nyata pada faktor perlakuan perbedaan awal waktu pemberian pakan pasca menetas terhadap total FCR sejalan dengan total konsumsi pakan dan PBB broiler periode starter dimana perlakuan pemberian pakan 12 jam pasca menetas menyebabkan total FCR lebih rendah atau lebih baik daripada perlakuan pemberian pakan 24 jam pasca menetas. Hal ini dibuktikan dengan rataan total FCR selama 3 minggu pemeliharaan pada perlakuan $\mathrm{W} 1$ sebesar 1,21 $\pm 0,05$, jauh lebih baik daripada W2 yang sebesar $1,39 \pm 0,17$. 
Tabel 3. Total Rataan FCR selama 3 minggu pemeliharaan

\begin{tabular}{lllll}
\hline \multirow{2}{*}{ Minggu ke- } & Suhu $(\mathrm{S})$ & \multicolumn{2}{l}{ Awal waktu pemberian pakan $(\mathrm{W})$} & \multirow{2}{*}{ Rataan } \\
\cline { 3 - 4 } I & W1 & $1,13 \pm 0,09$ & $1,19 \pm 0,08$ & $1,16 \pm 0,08$ \\
& S2 & $1,19 \pm 0,07$ & $1,18 \pm 0,03$ & $1,19 \pm 0,05$ \\
& Rataan & $1,16 \pm 0,08$ & $1,19 \pm 0,06$ & \\
II & S1 & $1,43 \pm 0,13$ & $1,49 \pm 0,08$ & $1,46 \pm 0,11$ \\
& S2 & $1,43 \pm 0,17$ & $1,57 \pm 0,09$ & $1,50 \pm 0,12$ \\
& Rataan & $1,43 \pm 0,11$ & $1,53 \pm 0,09$ & \\
III & S1 & $1,14 \pm 0,15$ & $1,27 \pm 0,16$ & $1,20 \pm 0,16$ \\
& S2 & $1,11 \pm 0,06$ & $1,50 \pm 0,37$ & $1,30 \pm 0,32$ \\
& Rataan & $1,12 \pm 0,11^{\mathrm{B}}$ & $1,38 \pm 0,29^{\mathrm{A}}$ & \\
\multirow{3}{*}{ Total } & S1 & $1,21 \pm 0,06$ & $1,32 \pm 0,07$ & $1,26 \pm 0,08$ \\
& S2 & $1,21 \pm 0,06$ & $1,46 \pm 0,23$ & $1,33 \pm 0,21$ \\
& Rataan & $1,21 \pm 0,05^{\mathrm{B}}$ & $1,39 \pm 0,17^{\mathrm{A}}$ & \\
\hline
\end{tabular}

Keterangan: Superskrip huruf yang berbeda pada baris yang sama (A, B) menunjukkan berbeda nyata $(\mathrm{P}<0,05) . \mathrm{S} 1=$ Suhu rendah; $\mathrm{S} 2=$ Suhu tinggi; $\mathrm{W} 1=$ Awal waktu pemberian pakan 12 jam; $\mathrm{W} 2=$ Awal waktu pemberian pakan $24 \mathrm{jam}$.

Pengaruh faktor perlakuan suhu terhadap total FCR broiler selama 3 minggu pemeliharaan pada penelitian ini tidak menunjukkan perbedaan signifikan. Walaupun demikian, rataan total FCR pada perlakuan S2 lebih buruk atau tinggi daripada S1. Ketidak seimbangan antara pakan yang dikonsumsi dengan PBB yang dihasilkan menyebabkan nilai FCR menjadi buruk atau mengalami kenaikan. Kenaikan nilai FCR dibuktikan dengan rataanFCR selama 3 minggu pemeliharaan perlakuan $\mathrm{S} 2$ yang mencapai $1,33 \pm 0,21$, lebih besar daripada $\mathrm{S} 1$ yang hanya 1,26 \pm 0,08 . Total FCR broiler periode starter selama 3 minggu pemeliharaan ditampilkan pada Gambar 3.

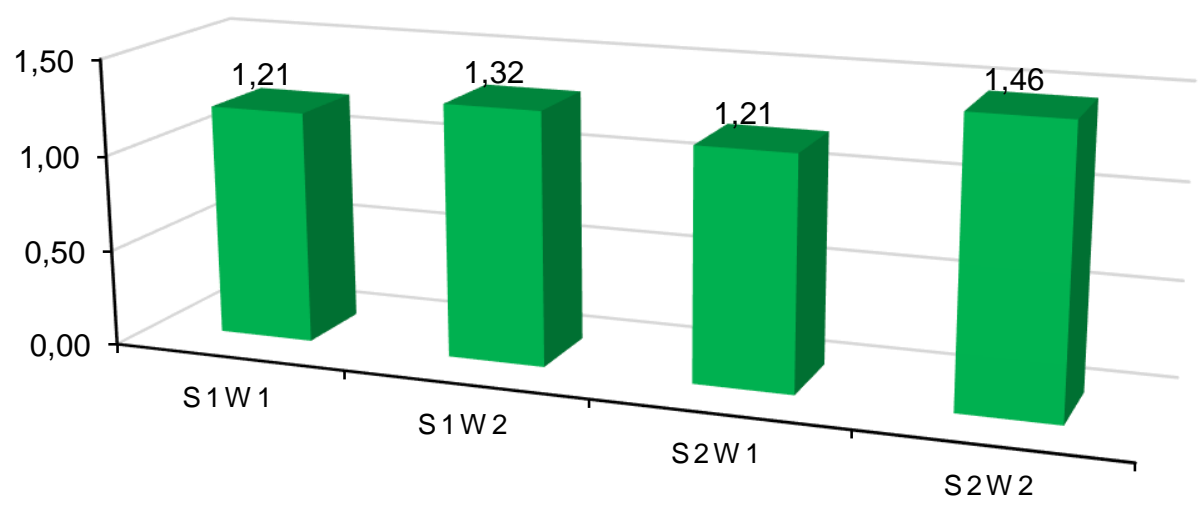

Gambar 3. Total FCR

Hasil penelitian ini didukung dengan hasil penelitian Luet al., (2007) yang menyatakan bahwa konversi pakan broiler umur 5-8 minggu yang dipelihara pada suhu $34^{\circ} \mathrm{C}$ dengan pemberian pakan ad libitum adalah 3,92 , nyata lebih tinggi 
dibandingkan dengan yang dipelihara pada suhu $21^{\circ} \mathrm{C}$ dengan konsumsi pakan_dibatasi dan ad libitum, yaitu masing-masing 3,21 dan 2,76. Geraert et al., (1996) juga melaporkan bahwa terjadi penurunan efisiensi pakan pada ayam yang dipelihara pada temperatur mencapai $32^{\circ} \mathrm{C}$.

\section{KESIMPULAN}

Cekaman panas berdampak negatif terhadap performa produksi broiler periode starter. Perbedaan awal waktu pemberian pakan pasca menetas mempengaruhi konsumsi pakan, PBB dan FCR broiler periode starter. Perlakuan suhu rendah dan awal pemberian pakan 12 jam pasca menetas menunjukkan hasil yang terbaik.

\section{SARAN}

Perlu dilakukan penelitian lebih lanjut misalnya dengan perlakuan cekaman dingin dan awal waktu pemberian pakan kurang dari 12 jam pasca menetas untuk melihat performa produksi pada broiler periode starter.

\section{DAFTAR PUSTAKA}

Bell, D. D., Weaver, W. D. 2002. Commercial Chicken Meat and Egg Production. $5^{\text {th }}$ Ed. New York: Springer Science Business Media, Inc.

Bhanja, S. K., Devi, C. A., Panda, A. K., and Sunder, G. S. 2009. Effect of posthatch feed deprivation on yolksac utilization and performance of young broiler chickens. Asian-Aust. J. Anim. Sci., 22(8), 1174-1179.

Charles, D. R. 2002. Responses to the thermal environment. In Poultry Environment Problem, A guide to solution. Nottingham, United Kingdom: Nottingham University Press.
Geraert, P. A., Padhilha, J.C.F., and Guillaumin, S. 1996. Metabolic and endocrine changes by chronic heat exposure in broiler chickens: biological and endocrinological variables. Br.J. Nutr. 75(2), 205-216.

Kuczynski, T. 2002. The application of poultry behaviour responses on heat stress to improve heating and ventilation system efficiency. Electr. J.pol. Agric. Univ, 5(1):1-11.

Kusnadi, E. 2007. Pengaruh Penambahan Pegagan (Centella asiatica) dan Vitamin $\mathrm{C}$ terhadap Kandungan Hemoglobin dan Hematokrit Darah Ayam Broiler yang Mengalami Cekaman Panas. Jurnal Ilmu Ternak, 7(2), 10-14.

Kusnadi, E., dan Rahim, F. 2009. Performa dan Kandungan Hormon Triiodotironin Plasma Ayam Broiler Akibat Pengaruh Cekaman Panas di Daerah Tropis. Media Peternakan, 32(3), 155-162.

Lu, Q., Wen, J., and Zhang, H. 2007. Effect of chronic heat exposure on fat deposition and meat quality in two genetic types of chicken. Poult. Sci. 86(6): 1059-1064.

North, M.O., and Bell, D.D. 1990. Commercial Chicken Production manual. $4^{\text {th }}$ Edition. Wesport Itaca. New York: The avi Pulishing Company Inc.

Tamzil, M. H., Noor, R. R., Hardjosworo, P. S., Manalu, W., and Sumantri, C. 2013. Acute heat stress responses of three lines of chickens with different heat shock protein (HSP)-70 genotypes. Intern J Poult Sci. 12(5), 264-272. 
Wahju, J. 2004. Ilmu Nutrisi Unggas. Yogyakarta: Gadjah Mada University Press.

Yunianto, V. D. 1999. Pengaruh cekaman dingin dan panas terhadap percepatan pembongkaran protein pada ayam broiler. Jurnal Pengembangan Peternakan tropis. 24(2), 90-96. 